\title{
EIGR - knowledge base as a tool facilitating the management of groundwater resources in Europe
}

\section{Introduction}

The sustainable management of natural resources, including groundwater resources, has become one of the challenges of the $21^{\text {st }}$ century. Water is a strategic resource from the point of view of, inter alia, human health, environmental protection, agriculture, cities development (UN 2003) and energy production (UN 2014). Proper water management is a key element of sustainable development, since it concerns the functioning of three areas - the society, the natural environment and the economy. All sectors of the economy need water to thrive and develop. In Europe, the main drivers of demand for water are power generation (44\%), agriculture (24\%), utilities (21\%) and industry and services (11\%) (EC 2017a).

A significant portion of fresh water resources is lost due to distribution system defects; in some countries, this percentage may be as high as $40 \%$. It is anticipated that the water demand from all sectors will increase by $16 \%$ by 2030 and that demand for water will be exacerbated by the effects of climate change in particular. At the same time, this demand must be balanced with the need to maintain a sufficient quantity and quality of water resources in the natural environment.

* Ph.D. Eng., AGH University of Science and Technology, Faculty of Geology, Geophysics and Environmental Protection, Krakow, Poland, e-mail: bts@agh.edu.pl

** M.Sc. Eng., Mineral and Energy Economy Research Institute, Polish Academy of Sciences, Krakow, Poland; e-mail: mdendys@min-pan.krakow.pl

*** D.Sc. Eng., Associate Professor of MEERI PAS, Mineral and Energy Economy Research Institute, Polish Academy of Sciences, Krakow, Poland; Polish Association of Mineral Asset Valuators; e-mail: krzysztof.galos@min-pan.krakow.pl 
Sustainable water management is among the main Sustainable Development Goals included in the 2030 Agenda for Sustainable Development (UN 2015, 2017). These goals have been established by the United Nations, but they form a priority axis that is coherent with the EU's policy objectives related to water management. This is particularly important now, after 2015, which was the deadline for achieving a good qualitative good qualitative and quantitative status of water under the Water Framework Directive (WFD 2000). Ensuring access to sufficient water resources of adequate quality plays a crucial role in transitioning towards a low-carbon, resource-efficient and climate-resilient economy in line with the Europe 2020 objectives (EC 2017b).

According to EU policy goals, water management should develop on the basis of new water management technologies, the elimination of knowledge gaps, and investment in water supply, infrastructure and innovation that reduces the risk of water scarcity and disasters such as droughts and floods (Kmiecik et al. 2006, 2008). Addressing these challenges, in its Horizon 2020 program the EU set forth in detail the areas of research and innovation related to water resources and sustainable in water management that are eligible for funding (EC 2017c). Funding under the Horizon 2020 program may be allocated to projects that involve actions contributing to the transition to a resource-saving economy and society that are resilient to climate change or to projects related to sustainable economy and the protection of natural resources and ecosystems.

One such project that received research and innovation funding under the Horizon 2020 program is the KINDRA project (http://kindraproject.eu/). The main purpose of the project is to carry out an EU-wide assessment of of the existing scientific and practical knowledge related to groundwater on the basis of the new Hydrogeological Research Classification System (HRC-SYS). The tool that enables this assessment is the European Inventory of Groundwater Research (EIGR). It is a repository of knowledge and also a tool that makes it possible to identify relevant topics, trends and research challenges. Project results will be used to guide the implementation of policies and optimization of water management in Europe. The KINDRA project and the EIGR combine research and knowledge and enable the integration of the academic environment with the business community that leverages practical knowledge about groundwater resources. In the KINDRA project Poland is represented by Polish Association of Mineral Asset Valuators, Linked Third Party of the project consortium. Polish experts in hydrogeology fields taking part in all tasks on the KINDRA project in an active way (Tomaszewska and Dendys 2016, 2017).

\section{Materials and methods}

The KINDRA project has been divided into three stages:

- WP1 - Methodology framework development;

- WP2 - Data collection and processing;

- WP3 - Research gaps and recommendations. 
The purpose of the first stage (WP1) was to create a framework for the classification of groundwater research results (sourced, inter alia, from scientific articles) and the results of activities undertaken in the area of water management (sourced from publications, reports or studies resulting from the implementation of projects, programs or own tasks by the bodies responsible for water management) (Fig. 1a).

In the first stage of the classification, keywords concerning groundwater studies were identified. These keywords were based on the most important EU directives and documents, including the Water Framework Directive (WFD 2000), Groundwater Directive (GD 2006) and the Blueprint to Safeguard Europe's Water Resources (BSEWR 2012) as well as on scientific literature on groundwater, which provided the basis for identifying links between the topics and the activities undertaken. Subsequently, the keywords were ranked according to search relevance in the Web of Science, Scopus and Google Scholar databases. The list of keywords included around 200 entries that were organized in a tree-like hierarchical structure (Fig. 1b). Three main categories were identified:

- Societal Challenges (SC);

- Operational Actions (OA);

- Research Topics (RT).

In each of the three main categories, five top-level groups were defined that represented the most important research areas. Subsequently, the remaining keywords were assigned to one of the top-level groups each, creating three more levels of the keyword hierarchy. At this project stage, the EIGR database was created as well. The EIGR is primarily a tool for collecting practical and scientific knowledge on groundwater in Europe, although ultimately it

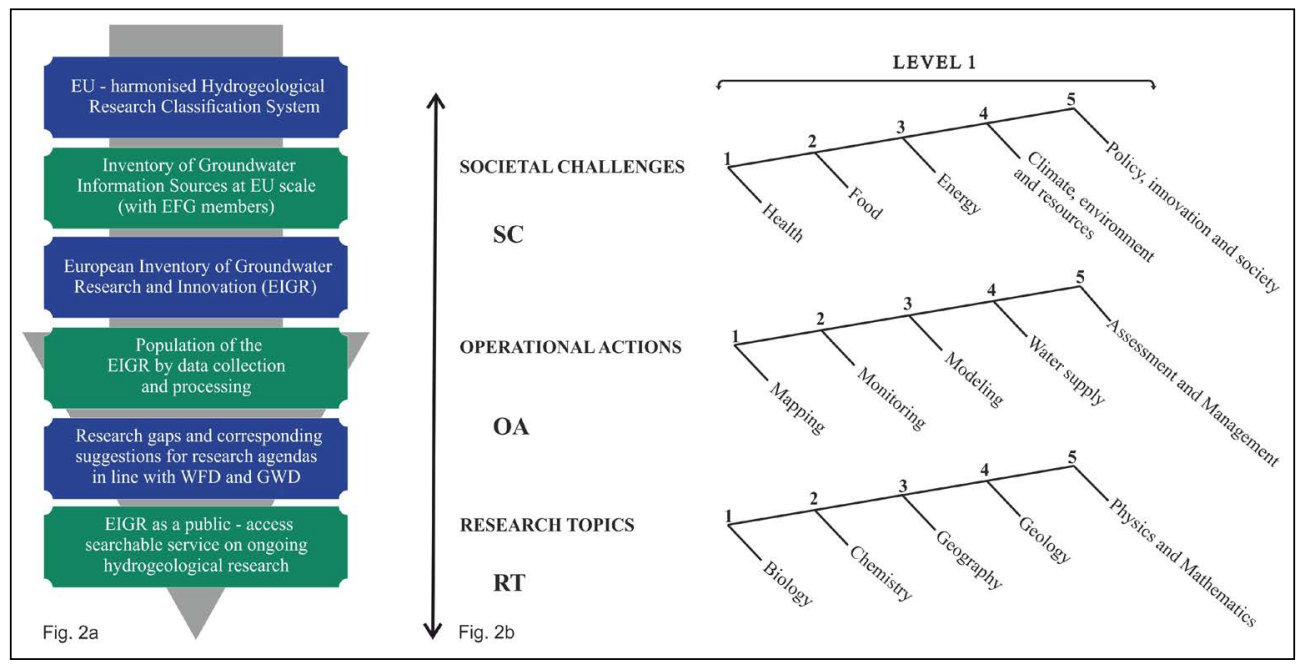

Fig. 1. a) KINDRA project stages b) Hierarchy tree in HRC-SYS classification (on the bases of http://kindraproject.eu/)

Rys. 1. a) Etapy projektu KINDRA b) Hierarchia drzewa w klasyfikacji HRC-SYS (na podstawie http://kindraproject.eu/) 
is also intended to promote the building of a community of people whose professional work is linked to groundwater, and to provide an international access point to sources of knowledge located in individual countries.

In 2016, in the second project stage (WP2), experts from individual European countries that participated in the KINDRA project populated the EIGR with materials and publications that met certain criteria. The EIGR platform functions as a directory of data with geographic references. However, the EIGR does not exclusively contain data, but also metadata (so-called data on data): information that is used to describe information resources and provides details on these resources. This information is used to facilitate the search for the identification and management of information resources. Metadata describe the content, its quality, format and other characteristics associated with data resources. A sample set of metadata might contain information such as data title and general description, the purpose of data creation and their its usability, dates of data creation and updates, the geographic location of the area concerned by the data, data owner, data usage criteria, restrictions or data set quality. This information allows users to more accurately identify and select the data sets that best meet their needs and requirements, which in turn enables more the efficient use of this data. The use of metadata is of particular importance with respect to the information resources created by the institutions and authorities responsible for implementing water management tasks. Using a database like the EIGR, these bodies are able to share information and use the results of activities undertaken by institutions or organizations with similar profiles. In the future, the EIGR will include contributions from the international community and the database will be available to users from different countries. Therefore there is a need to reduce the duplication of information while improving the coherence and quality of the geographic information included in the database. For this reason, the GeoNetwork 2.10.4 system was used in building the EIGR, which facilitates the management of information based on various standards.

The information entered in the EIGR had to be sufficiently complete to enable its future users to conduct thorough analyses, since in addition to serving as a repository of knowledge, the EIGR is also intended to enable searches for information, the generation of statistics and diagrams and the use of other functions that facilitate the use of catalogued information. The HRC-SYS has made it possible to classify the available materials (documents, publications, reports, studies and databases that were uploaded to the EIGR) in a uniform and harmonized manner.

\section{Results}

The materials placed by the Polish experts in the EIGR database were sourced mainly from information resources of institutions whose activities directly or indirectly regard the the management of groundwater resources, the implementation of sustainable development concepts and the protection of valuable groundwater resources. These include the Ministry 


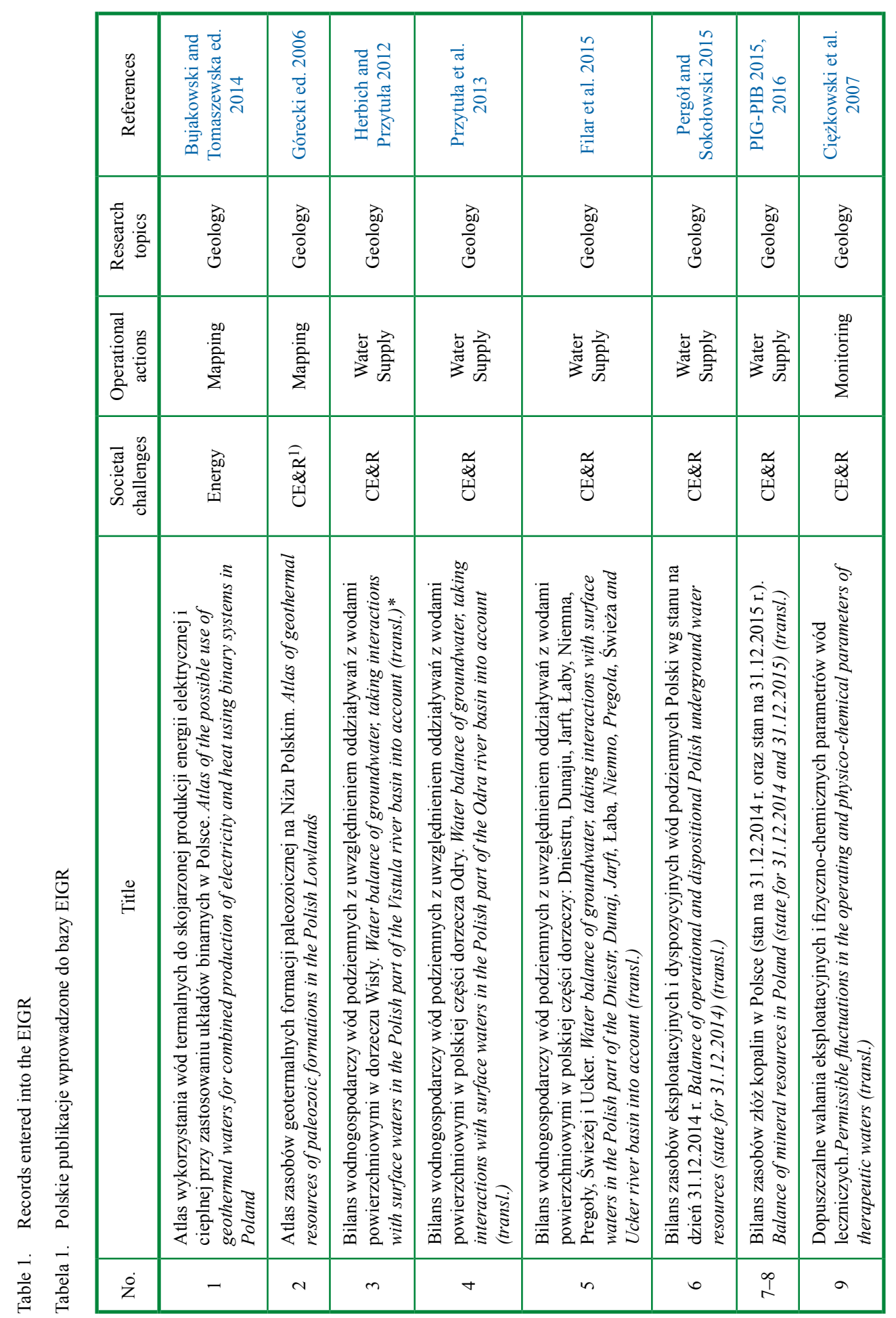




\begin{tabular}{|c|c|c|c|c|c|c|c|c|c|c|}
\hline 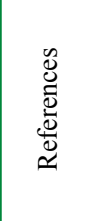 & 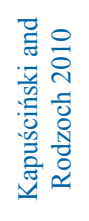 & 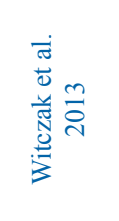 & 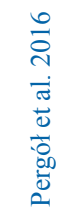 & 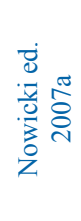 & 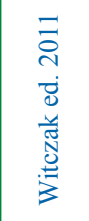 & 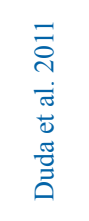 & 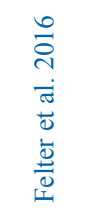 & 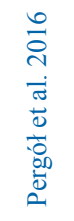 & 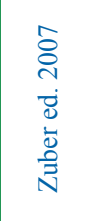 & 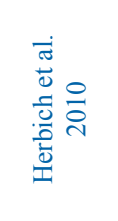 \\
\hline 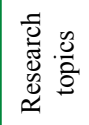 & 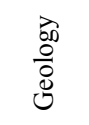 & 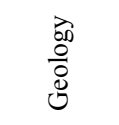 & 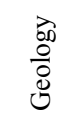 & 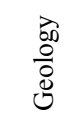 & 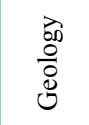 & 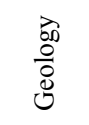 & $\begin{array}{l}\overrightarrow{0 D} \\
\stackrel{0}{0} \\
\stackrel{0}{0}\end{array}$ & 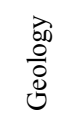 & $\begin{array}{l}\overrightarrow{0} \\
\text { Oें } \\
0 \\
0\end{array}$ & 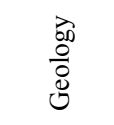 \\
\hline 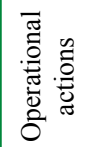 & 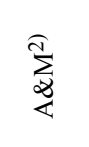 & 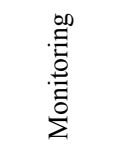 & 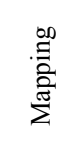 & $\begin{array}{l}\text { 品 } \\
\text { 产 } \\
\text { 首 }\end{array}$ & 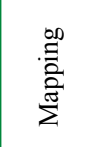 & 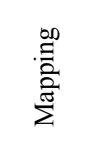 & $\begin{array}{l}\text { 品 } \\
\text { 产 } \\
\text { 离 }\end{array}$ & 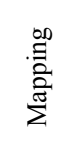 & 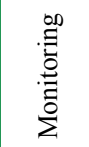 & $\underset{\alpha}{\alpha}$ \\
\hline 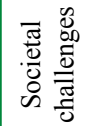 & $\begin{array}{l}\text { 总 } \\
\text { 岦 }\end{array}$ & $\begin{array}{l}\frac{1}{2} \\
\text { w } \\
\text { w }\end{array}$ & $\begin{array}{l}\frac{1}{2} \\
\text { w } \\
\text { w }\end{array}$ & 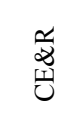 & 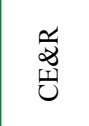 & 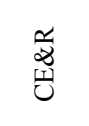 & $\begin{array}{l}\frac{1}{3} \\
\text { w } \\
\text { w }\end{array}$ & 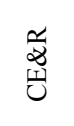 & 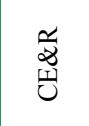 & $\begin{array}{l}\widetilde{\alpha} \\
\tilde{w} \\
\tilde{y}\end{array}$ \\
\hline$\stackrel{0}{B}$ & 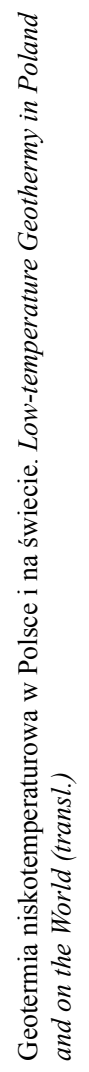 & 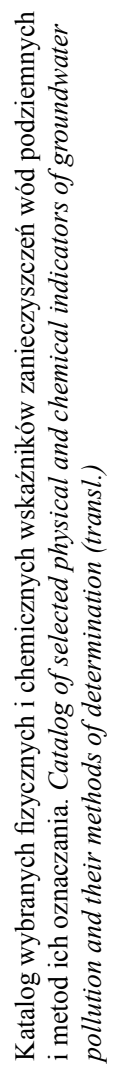 & 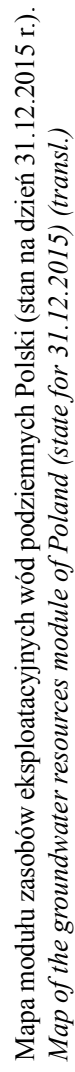 & 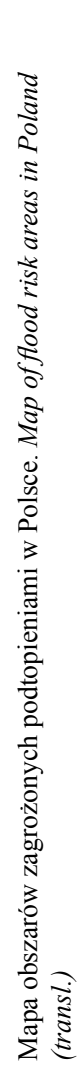 & 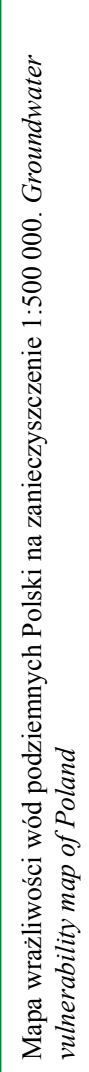 & 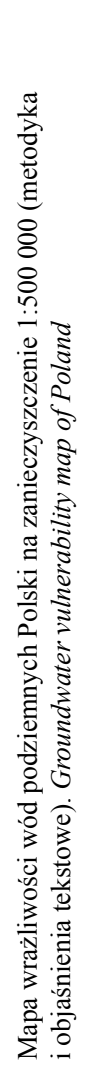 & 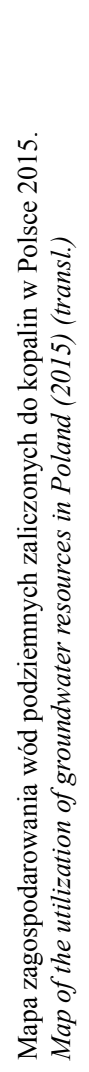 & 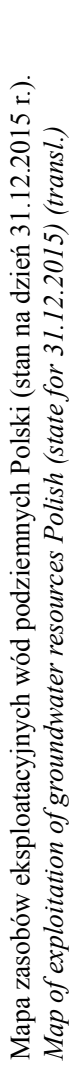 & 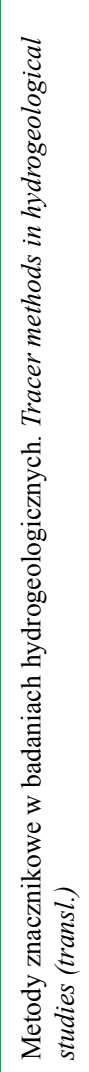 & 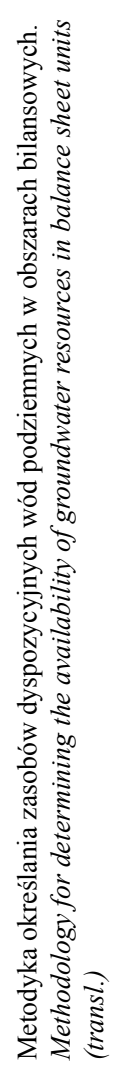 \\
\hline$\dot{z}$ & 으 & $=$ & $\simeq$ & 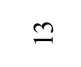 & \pm & 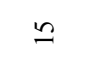 & $\stackrel{ }{\circ}$ & $=$ & $\stackrel{\infty}{\stackrel{0}{2}}$ & 9 \\
\hline
\end{tabular}




\begin{tabular}{|c|c|c|c|c|c|c|c|c|c|}
\hline 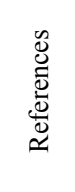 & 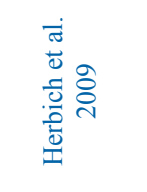 & 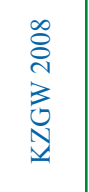 & 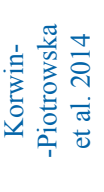 & 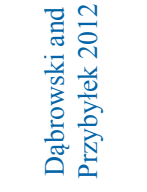 & 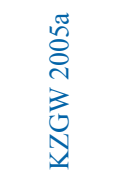 & 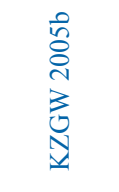 & 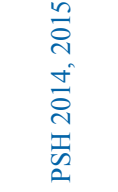 & 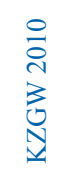 & 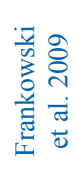 \\
\hline 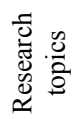 & $\begin{array}{l}\overleftrightarrow{c_{0}} \\
\stackrel{0}{0} \\
\stackrel{0}{0}\end{array}$ & 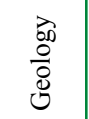 & $\begin{array}{l}\overrightarrow{00} \\
\frac{0}{0} \\
0 \\
0\end{array}$ & $\begin{array}{l}\overrightarrow{0} \\
\stackrel{0}{0} \\
\stackrel{0}{0} \\
0\end{array}$ & 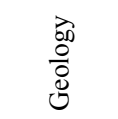 & 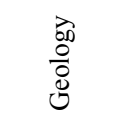 & $\begin{array}{l}\text { 总 } \\
\stackrel{0}{0} \\
0 \\
0\end{array}$ & $\begin{array}{l}\text { त्र } \\
\frac{0}{8} \\
0 \\
0\end{array}$ & 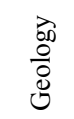 \\
\hline 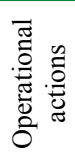 & $\sum_{\alpha}^{\infty}$ & $\sum_{\alpha}^{\infty}$ & 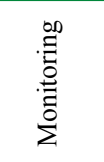 & 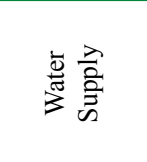 & $\sum_{\substack{\infty \\
<}}$ & $\sum_{\infty}^{\infty}$ & 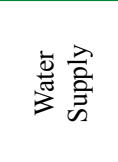 & 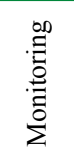 & 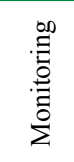 \\
\hline 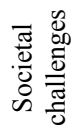 & $\begin{array}{l}\frac{a}{3} \\
\tilde{y} \\
\tilde{y}\end{array}$ & 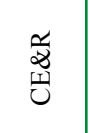 & 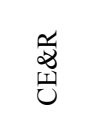 & $\begin{array}{l}\frac{\sqrt{3}}{3} \\
\text { wy }\end{array}$ & 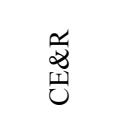 & 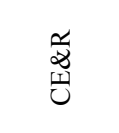 & $\begin{array}{l}\frac{\widetilde{3}}{3} \\
\text { 严 }\end{array}$ & 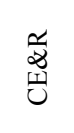 & 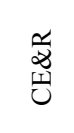 \\
\hline$\stackrel{\varrho}{\underline{E}}$ & 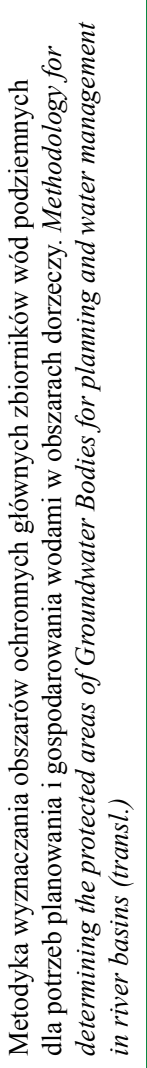 & 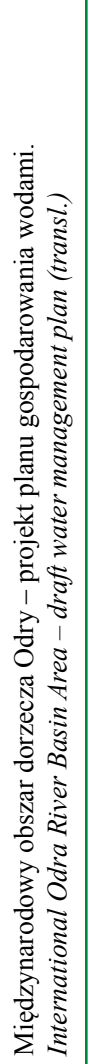 & 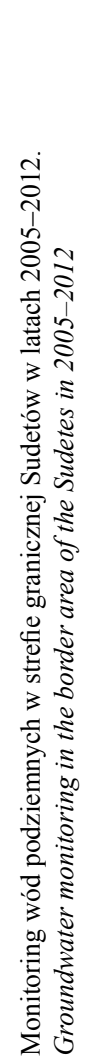 & 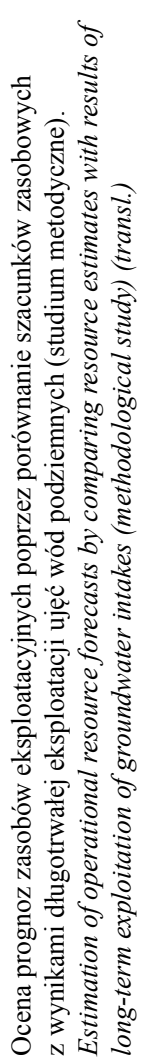 & 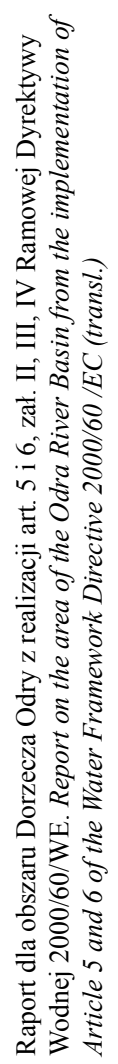 & 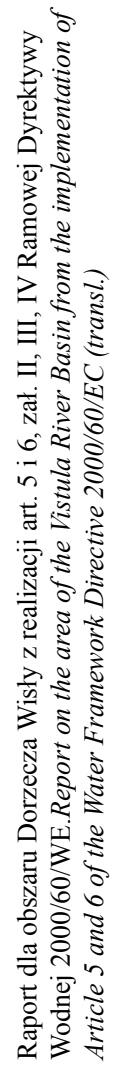 & 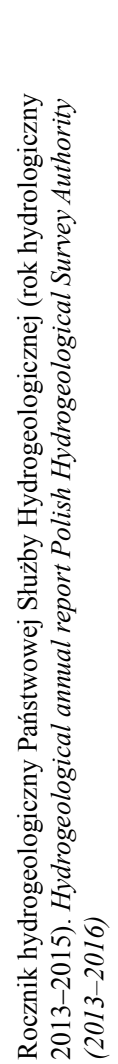 & 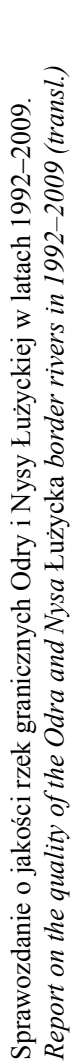 & 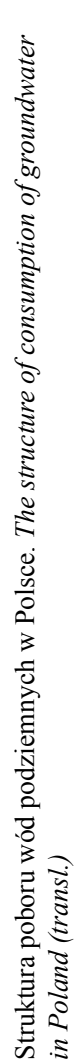 \\
\hline$\dot{z}$ & 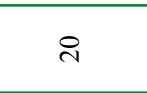 & $\vec{\sim}$ & $\tilde{\lambda}$ & $\tilde{i}$ & $\stackrel{4}{4}$ & ¿n & $\begin{array}{l}\infty \\
\text { d } \\
\text { d. }\end{array}$ & ते & in \\
\hline
\end{tabular}




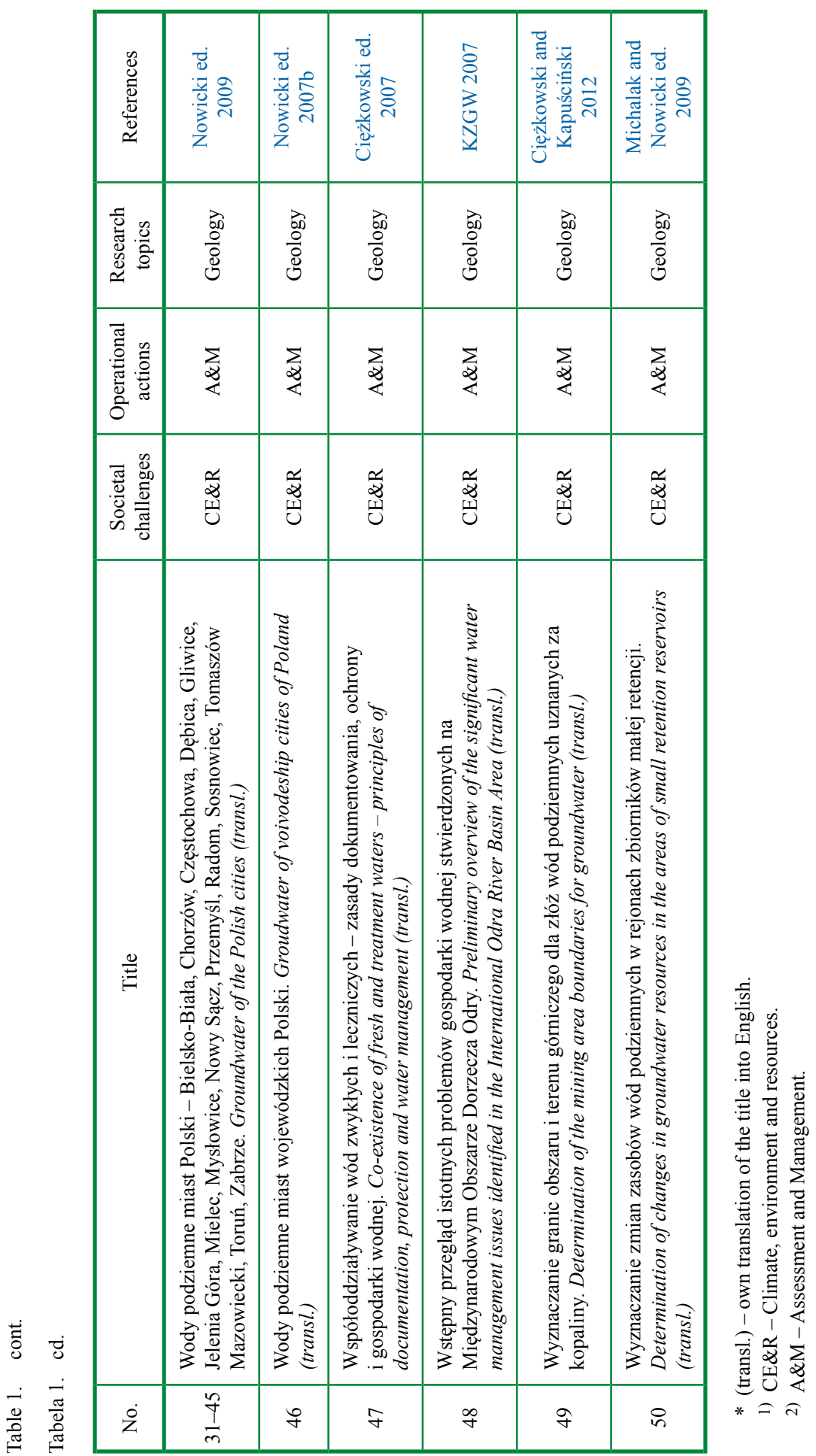


of the Environment, the National Fund for Environmental Protection and Water Management, the National Board of Water Management, the Hydrogeological Service and the Chief Inspectorate of Environmental Protection. These institutions carry out their own tasks and finance projects, the results of which are published on their official websites in the form of reports, studies, maps, guides, balance sheet or methodological manuals. The criterion for selecting individual materials was the reliability of information and whether the subject matter was related to groundwater (groundwater resources, quantitative and qualitative monitoring, hydrogeochemical studies, geothermal waters, etc.) in the context of the entire country or large areas thereof (e.g. the Vistula and Odra River basin, Main Groundwater Reservoirs). Additionally, materials that contained universal content related to conducting hydrogeological research were selected for the database.

A total of 50 publications were placed in the EIGR database (reports, data reports, popular journals, newsletters, etc. with no certain Operational Actions (OA) (Table 1):

- national and local reports containing facts and data - 16 inputs;

- hydrogeological maps - 6 inputs;

- technical reports, guidelines, manuals, etc. -9 inputs;

- books and book chapters - 17 inputs;

- atlases -2 inputs.

The records entered into the EIGR were also analyzed with respect to their HRC-SYS classification to determine the proportions of individual items from the three main thematic groups: i) Societal Challenges (SC); ii) Operational Actions (OA); and iii) Research Topics (RT). In the SC group, two items were classified as belonging to the "Energy" area (4\%), while the remaining 48 items were classified as "Climate, Environment and Resources" (96\%). Larger diversity was observed in the OA group. The "Assessment and Management" area included 26 items (52\%), and the "Mapping" and "Monitoring" areas numbered 8 and 6 items, respectively (16 and 12\%), while the "Water Supply" area included 10 items (20\%). In the RT group, all the items entered in the database were classified as belonging to the "Geology" area (100\%).

Only the data is available directly from the official websites of the relevant institutions and is not not subject to any special intellectual property rights or other restrictions on the use of content was entered in the EIGR database.

\section{Conclusions}

In the third stage of the project (WP3), thematic gaps will be identified within hydrogeological research that is relevant for the implementation of the Water Framework Directive and for a deeper understanding of interrelationships between groundwater and surface water as well as of the impact of climate change on water management and the need to adapt to this change. Work in this area will include an assessment of the data collected in the EIGR, which will be carried out by a panel of experts. The identification of the research gaps will 
also result in the formulation of proposals concerning updates to, and the development of, programs that support research and innovation.

Participation in the KINDRA project and work on the creation of the EIGR have made it possible to draw some conclusions about information resources and the potential of the practical knowledge present in Poland. When populating the EIGR database, several barriers and information gaps were encountered. One of them is the insufficient number of publications that indicate that Poland is an active participant of international cooperation in the field of water management. One reason is perhaps that the Polish territory is almost entirely covered by the catchment areas of the Vistula and Odra Rivers and virtually the entire southern border of Poland runs along watersheds, which makes the subject of managing water resources within certain basins an exclusively Polish preoccupation. As concerns the methodology of hydrogeological research, on the other hand, there are many valuable publications that could serve as sources of useful information to the international community. Unfortunately, the vast majority of materials are published exclusively in Polish, and thus the practical knowledge contained therein reaches only Polish recipients. Additionally, just a several publications had alternative English titles and abstracts, which considerably limits the target audience and means that opportunities are wasted, since materials that are often valuable will not be used or promoted outside Poland. One solution to this problem could be the practice followed at many scientific journals, including those that are published exclusively in Polish: providing at least an alternative English version of the title, and in some cases also an English abstract. This solution would certainly support the flow and dissemination of information as well as the exchange of experience between individuals and bodies whose activities relate to groundwater and water management.

As a result of the KINDRA project, the EIGR database has two very important features. Firstly, the EIGR will be a publicly available practical knowledge base that can be used by everyone who seeks knowledge related to groundwater and water management. Secondly, and perhaps most importantly, this database will enable updates and additions by individuals and representatives of institutions who want to share the results of their work and their knowledge. Thus the project will not only result in creating a knowledge base that may provide a useful tool for the implementation of water management activities, but it will also contribute to building a community focused on groundwater-related topics.

\section{Acknowledgements}

The presented work was funded by the European Union's Horizon 2020 Research and Innovation Program (grant agreement No 642047). 


\section{REFERENCES}

BSEWR 2012 - Directive 2006/118/EC Of The European Parliament And Of The Council Of 12 December 2006 On The Protection Of Groundwater Against Pollution And Deterioration (Official Journal of the European Union 27.12.2006 L 372/19) (in Polish).

Bujakowski, W. and Tomaszewska, B. ed. 2014. Atlas wykorzystania wód termalnych do skojarzonej produkcji energii elektrycznej i cieplnej przy zastosowaniu uktadów binarnych w Polsce. Kraków: Wyd. Jak, 310 pp. (in Polish).

Ciężkowski et al. 2007 - Ciężkowski, W., Kiełczawa, B., Latour, T., Liber, E., Przylibski, T., Sziwa, D. and Żak, S. 2007. Dopuszczalne wahania eksploatacyjnych i fizyczno-chemicznych parametrów wód leczniczych. Wrocław: Oficyna Wydawnicza Politechniki Wrocławskiej, 84 pp. (in Polish).

Ciężkowski, W. and Kapuściński, J. 2012. Wyznaczanie granic obszaru i terenu górniczego dla złóż wód podziemnych uznanych za kopaliny. Warszawa: Borgis Wydawnictwo Medyczne, 98 pp. (in Polish).

Ciężkowski, W. ed. 2007. Współoddziaływanie wód zwykłych i leczniczych-zasady dokumentowania, ochrony i gospodarki wodnej. Wrocław: Oficyna Wydawnicza Politechniki Wrocławskiej, 76 pp. (in Polish).

Dąbrowski, S. and Przybyłek, J. 2012. Ocena prognoz zasobów eksploatacyjnych poprzez porównanie szacunków zasobowych z wynikami długotrwałej eksploatacji ujęć wód podziemnych (studium metodyczne). Poznań: Bogucki - Wydawnictwo Naukowe, 462 pp. (in Polish).

Duda et al. 2011 - Duda, R., Witczak, S. and Żurek, A. Mapa wrażliwości wód podziemnych Polski na zanieczyszczenie 1:500 000 (metodyka i objaśnienia tekstowe). Kraków: AGH, 139 pp. (in Polish).

EC 2017a. European Commission (EC). Agriculture and Sustainable Water Management in the UE. Commission Staff Working Document. [Online] Available at: https://circabc.europa.eu/sd/a/abff972e-203a-4b4e-b42e-a0f291d3fdf9/SWD_2017_EN_V4_P1_885057.pdf [Accessed: 01.10.2017].

EC 2017b. European Commission (EC). Europe 2020 targets: statistics and indicators at EU level. [Online] Available at: https://ec.europa.eu/info/strategy/european-semester/framework/drafteurope-2020-strategy/europe2020-targets-statistics-and-indicators-eu-level_en [Accessed: 01.10.2017].

EC 2017c. European Commission (EC). What is Horizon 2020?. [Online] Available at: https://ec.europa.eu/programmes/horizon2020/en/what-horizon-2020 [Accessed: 01.10.2017].

Felter et al. 2016 - Felter, A., Skrzypczyk, R., Socha, M., Sokołowski, J., Stożek, J. and Gryczko-Gostyńska, A Mapa zagospodarowania wód podziemnych zaliczonych do kopalin w Polsce 2015. Warszawa: PIG-PIB, 1 map (in Polish).

Filar et al. 2015 - Filar, S., Mordzonek, G., Przytuła, E. and Węglarz, D. 2015. Bilans wodnogospodarczy wód podziemnych z uwzględnieniem oddziaływań z wodami powierzchniowymi w polskiej części dorzeczy: Dniestru, Dunaju, Jarft, Łaby, Niemna, Pregoły, Świeżej i Ucker. Warszawa: PIG-PIB, 90 pp. (in Polish).

Frankowski et al. 2009 - Frankowski, Z., Gałkowski, P. and Mitręga, J. 2009. Struktura poboru wód podziemnych w Polsce. Warszawa: PIG, 163 pp. (in Polish).

GD 2006 - Communication From The Commission To The European Parliament, The Council, The European Economic And Social Committee And The Committee Of The Regions A Blueprint To Safeguard Europe's Water Resources /* Com/2012/0673 Final. [Online] Available at: http://eur-lex.europa.eu/legal-content/EN/TXT/ HTML/?uri=CELEX:52012DC0673\&from=EN [Accessed: 01.10.2017].

Górecki, W. ed. 2006. Atlas zasobów geotermalnych formacji paleozoicznej na Niżu Polskim. Kraków: AGH, 241 pp.

Herbich et al. 2009 - Herbich, P., Kapuściński, J., Nowicki, K., Prażak, J. and Skrzypczyk, L. 2009. Metodyka wyznaczania obszarów ochronnych głównych zbiorników wód podziemnych dla potrzeb planowania i gospodarowania wodami w obszarach dorzeczy. Warszawa: Ministerstwo Środowiska, 59 pp. (in Polish).

Herbich et al. 2010 - Herbich, P., Kapuściński, J., Nowicki, K. and Rodzoch, A. 2010. Metodyka określania zasobów dyspozycyjnych wód podziemnych w obszarach bilansowych. Warszawa: Borgis Wydawnictwo Medyczne, 271 pp. (in Polish).

Herbich, P. and Przytuła, E. 2012. Bilans wodnogospodarczy wód podziemnych z uwzględnieniem oddziaływań z wodami powierzchniowymi w dorzeczu Wisły. Warszawa: PIG-PIB, 125 pp. (in Polish).

Kapuściński J. and Rodzoch A. 2010. Geotermia niskotemperaturowa w Polsce i na świecie. Warszawa: Borgis Wydawnictwo Medyczne, 140 pp. (in Polish). 
Kmiecik et al. 2006 - Kmiecik E., Stach-Kalarus M., Szczepanska J., Twardowska I., Stefaniak S. and Janta-Koszuta K. 2006. Assessment of groundwater chemical status based on aggregated data from a monitoring network exemplified in a river drainage basin. Proceedings Of The Society Of Photo-Optical Instrumentation Engineers (Spie), 2006, Vol. 6377, p. U141-U150. DOI: 10.1117/12.686367.

Kmiecik et al. 2008 - Kmiecik, E., Szczepanska, J., Twardowska, I. and Stefaniak, S. 2008. Assessing chemical status of shared groundwater resources: A crucial political, regulatory and management issue. In: Overexploitation And Contamination Of Shared Groundwater Resources: Management, (Bio) Technological, And Political Approaches To Avoid Conflicts. Book Series: Nato Science for Peace and Security Series C - Environmental Security, 2008. pp. 325-354. DOI: 10.1007/978-1-4020-6985-7_16.

Korwin-Piotrowska et al. 2014 - Korwin-Piotrowska, A., Serafin, R., Wojtkowiak, A., Krawczyk, J., Skrzypczak, L., Zawistowski, K., Chudzik, L., Biel, A., Koroš, I., Uhlik, J. and Eckhardt, P. 2014. Monitoring wód podziemnych w strefie granicznej Sudetów w latach 2005-2012. Warszawa: PIG-PIB, 101 pp. (in Polish).

KZGW 2005a. Raport dla obszaru Dorzecza Wisty z realizacji art. 5 i 6, zat. II, III, IV Ramowej Dyrektywy Wodnej 2000/60/WE. Warszawa: Krajowy Zarząd Gospodarki Wodnej (KZGW), 291 pp.. (in Polish)

KZGW 2005b. Raport dla obszaru Dorzecza Wisty z realizacji art. 5 i 6, zal. II, III, IV Ramowej Dyrektywy Wodnej 2000/60/WE. Warszawa: Krajowy Zarząd Gospodarki Wodnej (KZGW), 389 pp. (in Polish).

KZGW 2007. Wstępny przegląd istotnych problemów gospodarki wodnej stwierdzonych na Międzynarodowym Obszarze Dorzecza Odry. Warszawa: Krajowy Zarząd Gospodarki Wodnej (KZGW), 8 pp. (in Polish).

KZGW 2008. Międzynarodowy obszar dorzecza Odry - projekt planu gospodarowania wodami. Warszawa: Krajowy Zarząd Gospodarki Wodnej (KZGW), 88 pp. (in Polish).

KZGW 2010. Sprawozdanie o jakości rzek granicznych Odry i Nysy Łużyckiej w latach 1992-2009. Wrocław: Grupa Robocza W2 „Ochrona Wód“ Polsko-Niemieckiej Komisji ds. Wód Granicznych, 30 pp. (in Polish).

Michalak J. and Nowicki Z. ed. 2009. Wyznaczanie zmian zasobów wód podziemnych w rejonach zbiorników małej retencji. Warszawa: Państwowy Instytut Geologiczny, 110 pp. (in Polish).

Nowicki Z. ed. 2007a - Mapa obszarów zagrożonych podtopieniami w Polsce. Warszawa: Państwowy Instytut Geologiczny - Państwowa Służba Hydrogeologiczna, 19 pp. (in Polish).

Nowicki Z. ed. 2007b. Wody podziemne miast wojewódzkich Polski. Warszawa: Państwowy Instytut Geologiczny Państwowa Służba Hydrogeologiczna, 280 pp. (in Polish).

Nowicki Z. ed. 2009 - Wody podziemne miast Polski. Warszawa: Państwowy Instytut Geologiczny - Państwowa Służba Hydrogeologiczna. Bielsko-Biała - Chowaniec, J., Freiwald, P. and Witek, K., 18 pp., Chorzów - Cudak, J. and Wantuch, A., 16 p., Częstochowa - Pacholewski, A., Zembal, M. and Wantuch, A., 20 pp., Dębica - Jarmułowicz-Siekiera, M., Olędzka, D., Owsiak, P. and Patorski, R., 18 pp., Gliwice - Chmura, A. and Wantuch, A., 16 pp., Jelenia Góra - Zawistowski, K. and Michniewicz, M., 22 pp., Mielec - Kowalczyk, A., 17 pp., Mysłowice - Stępińska-Drygała, I. and Wagner, J., 22 pp., Nowy Sącz - Gryczko-Gostyńska, A. and Olędzka, D., 16 pp., Przemyśl - Gryczko-Gostyńska, A., Witek, K. and Śliwiński, Ł., 16 pp., Radom - Chowaniec J., Freiwald, P., Owsiak, P., Patorski, R. and Witek, K., 15 pp., Sosnowiec - Wagner, J., Rolka, M. and Zembal, M., 22 pp., Tomaszów Mazowiecki - Nowicki, Z., Jarmułowicz-Siekiera, M. and Olędzka, D., 20 pp., ToruńLidzbarski, M. and Prussak, E., 15 pp., Zabrze - Razowska-Jaworek, L., Chmura, A. and Wantuch, A., 16 pp. (in Polish).

Pergół et al. 2016 - Pergół, S., Gałkowski, P. and Kublik, J 2016. Mapa zasobów eksploatacyjnych wód podziemnych Polski (stan na dzień 31.12.2015 r.). Warszawa: Państwowy Instytut Geologiczny - Państwowa Służba Hydrogeologiczna, 1 map (in Polish).

Pergół, S. and Sokołowski, J. 2015. Bilans zasobów eksploatacyjnych i dyspozycyjnych wód podziemnych Polski wg stanu na dzień 31.12.2014 r. Warszawa: Państwowy Instytut Geologiczny - Państwowa Służba Hydrogeologiczna, 28 pp. (in Polish).

PIG-PIB 2015. Bilans zasobów złóż kopalin w Polsce (stan na 31.12.2014 r.). Warszawa: PIG-PIB, 486 pp. (in Polish).

PIG-PIB 2017. Bilans zasobów złóż kopalin w Polsce (stan na 31.12.2016 r.). Warszawa: PIG-PIB, 476 pp. (in Polish).

Przytuła et al. 2013 - Przytuła, E., Filar, S. and Mordzonek, G. 2013. Bilans wodnogospodarczy wód podziemnych z uwzględnieniem oddziaływań z wodami powierzchniowymi w polskiej części dorzecza Odry. Warszawa: PIG-PIB, 89 pp. (in Polish).

PSH 2014. Rocznik hydrogeologiczny Państwowej Stużby Hydrogeologicznej (rok hydrologiczny 2013). Warszawa: Państwowy Instytut Geologiczny - Państwowa Służba Hydrogeologiczna (PSH), 483 pp. (in Polish). 
PSH 2015. Rocznik hydrogeologiczny Państwowej Stużby Hydrogeologicznej (rok hydrologiczny 2014). Warszawa: Państwowy Instytut Geologiczny - Państwowa Służba Hydrogeologiczna (PSH), 522 pp. (in Polish).

PSH 2016. Rocznik hydrogeologiczny Państwowej Stużby Hydrogeologicznej (rok hydrologiczny 2014). Warszawa: Państwowy Instytut Geologiczny - Państwowa Służba Hydrogeologiczna (PSH), 514 pp. (in Polish).

Tomaszewska, B. and Dendys, M. 2016. Projekt Kindra: dostępność informacji o wodach podziemnych w Polsce na tle innych krajów europejskich. Technika Poszukiwań Geologicznych, Geotermia, Zrównoważony Rozwój 55 (2), pp. 179-188, (in Polish)

Tomaszewska B. and Dendys M. 2017. Stan wiedzy naukowej i praktycznej dotyczącej gospodarki wodami podziemnymi w Polsce [In:] HPPH 2017: Hydrogeologia w praktyce - praktyka w hydrogeologii. Zbiór abstraktów. Polanica-Zdrój, 14-17 maja 2017 r. Główny Instytut Górnictwa, 72 pp. (in Polish).

UN 2003. United Nations (UN). Water for People, Water for Life. [Online] Available at: http://www.unesco.org/new/ en/natural-sciences/environment/water/wwap/wwdr/wwdr1-2003/downloads/ [Accessed: 01.10.2017].

UN 2014. United Nations (UN). Water and Energy. [Online] Available on: http://www.unesco.org/new/en/natural -sciences/environment/water/wwap/wwdr/2014-water-and-energy/ [Accessed: 01.10.2017]

UN 2015. United Nations (UN). Water for a Sustainable World. [Online] Available at: http://www.unesco.org/new/ en/loginarea/natural-sciences/environment/water/wwap/wwdr/2015-water-for-a-sustainable-world/ [Accessed: 01.10.2017]

UN 2017. United Nations (UN). Sustainable Development Goals. [Online] Available at: http://www.un.org/sustaina bledevelopment/sustainable-development-goals/ [Accessed: 01.10.2017].

WFD 2000. EU Water Framework Directive (WFD). Directive 2000/60/EC of the European Parliament and of the Council of 23 October 2000 establishing a framework for Community action in the field of water policy. Brussels: European Parliament.

Witczak et al. 2013 - Witczak, S., Kania, J. and Kmiecik, E. 2013. Katalog wybranych fizycznych i chemicznych wskaźników zanieczyszczeń wód podziemnych i metod ich oznaczania. Warszawa: Inspekcja Ochrony Środowiska, 717 pp. (in Polish).

Witczak, S. ed. 2011. Mapa wrażliwości wód podziemnych Polski na zanieczyszczenie 1:500 000. Kraków: AGH, 1 map (in Polish).

Zuber, A. ed. 2007. Metody znacznikowe w badaniach hydrogeologicznych. Wrocław: Oficyna Wydawnicza Politechniki Wrocławskiej, 399 pp. (in Polish).

\title{
EIGR - BAZA WIEDZY JAKO NARZĘDZIE WSPOMAGAJĄCE GOSPODAROWANIE ZASOBAMI WÓD PODZIEMNYCH W EUROPIE
}

\author{
Słowa kluczowe
}

projekt KINDRA, Horyzont 2020, wody podziemne, baza danych

\section{Streszczenie}

Uregulowania wynikające z Ramowej Dyrektywy Wodnej 200/60/WE zostały wprowadzone przez kraje Unii Europejskiej do ich systemu prawnego. Wytyczne wspomnianej dyrektywy wymagają, aby państwa członkowskie kontynuowały działania dla poprawy jakości wód w celu osiągnięcia co najmniej dobrego stanu wód powierzchniowych i podziemnych. Te kwestie zwracają uwagę na źródła antropopresji i wdrażają standardy dla kontroli szkodliwych zanieczyszczeń wprowadzanych do wód powierzchniowych wraz ze ściekami. W artykule przedstawiono zależność pomiędzy wymaganiami dla pozwoleń wodnoprawnych w polskim systemie prawnym na tle planów gospodarowania wodami na obszarze dorzecza. Projekt KINDRA jest realizowany w ramach programu „Horyzont 2020”. 
Jej głównym celem jest przeprowadzenie ogólnoeuropejskiej oceny stanu wiedzy praktycznej i naukowej dotyczącej wód podziemnych w oparciu o innowacyjny system klasyfikacji - Hydrogeological Research Classification System (HRC-SYS). Ocena ta będzie oparta na repozytorium wiedzy, europejskim wykazie badań wód gruntowych (EIGR). Baza danych EIGR ma również służyć jako narzędzie funkcjonalne, które zapewni możliwość wykorzystywanej informacji przez osoby fizyczne i przedstawicieli wszystkich instytucji, których działalność obejmuje zarządzanie wodami podziemnymi i powierzchniowymi. Celem tego artykułu jest przedstawienie głównych założeń projektu KINDRA oraz metodologii tworzenia bazy danych EIGR, ze szczególnym uwzględnieniem doświadczenia ekspertów, którzy reprezentują Polskę. Przedstawione materiały i informacje skierowane jako element do projektu EIGR, pozwoliły na dokonanie przeglądu i oceny aktualnego stanu wiedzy oraz publikacji wynikających z podejmowanych w Polsce działań w zakresie gospodarki wodnej.

\section{EIGR - KNOWLEDGE BASE AS A TOOL FACILITATING THE MANAGEMENT OF GROUNDWATER RESOURCES IN EUROPE}

\section{Keywords}

KINDRA project, Horizon 2020, groundwater, database

\section{Abstract}

The KINDRA project is being implemented within the framework of the Horizon 2020 programme. Its main purpose is to carry out an EU-wide assessment of existing practical and scientific knowledge related to groundwater on the basis of an innovative classification system - the Hydrogeological Research Classification System (HRC-SYS). This assessment will be based on the knowledge repository, the European Inventory of Groundwater Research (EIGR). The EIGR database is also intended as a functional tool that will provide knowledge resources to be used by individuals and representatives of all institutions whose activities involve groundwater and water management.

The purpose of this article is to outline the main assumptions underlying the KINDRA project and to present the methodology for creating the EIGR database, placing particular emphasis on the experience of experts who represent Poland. The materials and information they prepared as contributions to the EIGR have made it possible to review and evaluate the current state of the art as well as the publications resulting from the water management activities undertaken in Poland. 